\title{
Works about John Dewey 1886 - 1995, completed and edited by Barbara Levine, Southern Illinois University Press, Carbondale \& Edwardsville 1996, ss. 526
}

Do dnia dzisiejszego w Stanach Zjednoczonych rośnie zainteresowanie naukową twórczością klasyka wychowania pragmatycznego, pedagoga, filozofa, znakomitego teoretyka i praktyka w dziedzinie edukacji - Johna Deweya. Zjawisko to spowodowało, iż dr Barbara Levine zebrała i opublikowała ogromny materiał bibliograficzny w książce pod tytulem ,Works about John Dewey 1886-1995” (,Prace o Johnie Deweyu 1886 - 1995") wydanej w 1996 roku. Stanowi ona poważny zbiór publikacji ksiażkowych i artykułów ukazujacych się w czasopismach amerykańskich o bardzo zróżnicowanym profilu.

W przedmowie do książki autorka objaśnia, iż jest to już trzecia edycja, która ukazała się $w$ zwiększonym formacie $i$ pod nowym tytułem (pierwszy brzmiał - „Zbiór materiałów o Johnie Deweyu" i ukazał się w dwóch edycjach, pierwsza w 1974, druga w 1978 r.). Materiał obydwu wydań znajduje się $w$ omawianej ksiażce wraz $\mathrm{z}$ najnowszymi nazwiskami $\mathrm{i}$ tytułami powiększajacymi zasięg recepcji twórczości Johna Deweya, aż do 1995 roku. Zawarta jest więc bibliografia prac opublikowanych na temat J. Deweya na przestrzeni 108 lat, to znaczy od 1886 do 1994. Dodatkowo można w niej odnaleźć materiały, które ukazały się do kwietnia 1995 roku.

Omawiane wydanie różni się od dwóch poprzednich tym, iż w pierwszych, data rozpoczynająca nieustannie trwająca recepcję dzieł klasyka jest rok 1887. Faktycznie jednak badania Barbary Levine doprowadziły do daty 1886 jako pierwszej. Wtedy bowiem ukazała się odpowiedź H.S. Swifta na artykuł Johna Deweya „Odrodzenie duszy", oraz odpowiedź Shadwortha Hodgsona na artykuł J. Deweya pod tytułem ,Z psychologicznego punktu widzenia". Następne daty wciąż sięgaja końca dziewiętnastego wieku i tak w 1897 ukazał się artykuł Georga P. Browna pod tytukem ,Eksperyment edukacyjny doktora Johna Deweya" w PUBLIC SCHOOL JOURNAL No. 16, a w 1898 ukazał się artykuł Jamesa Marka Baldwina pod tytułem „Społeczne interpretacje: odpowiedź" w PHILOSOPHICAL REVIEW No. 7 będący odpowiedzia na artykuł Johna Deweya, który był zarazem recenzją eseju Baldwina dotyczacego rozwoju umysłowego $w$ interpretacji społeczno-etycznej. Przytoczony przeze mnie materiat już wtedy stanowiący zręby recepcji twórczości Johna Deweya pozwoli na krótki wgląd $w$ osobę samego filozofa.

John Dewey urodzil się w 1859, zmarł w 1952. Ponieważ książka Barbary Levine zaczyna się rokiem 1886 warto więc zaznaczyć, że w tym roku Dewey miał dopiero 27 lat, co nie przeszkadzało mu dwa lata wcześniej podją́ pracę w katedrze filozofii na Uniwersytecie Michigan, a cztery lata później, w 1888 roku na tymże uniwersytecie został mianowany profesorem filozofii. Doktorat z filozofii zrobił już w 1884 roku. Bardzo bogata działalność Johna Deweya na polu naukowym, nie w jednej, a w kilku dyscyplinach musiała więc zaowocować tak nieprzebraną ilościa materiałów odnoszących się do twórczości pedagoga, będacych poparciem jego poglądów bądź otwartą polemiką.

Chociaż autorka zawarła w swojej książce kilka tysięcy tytułów, jak sama pisze nie uważa tej bibliografii za wyczerpujaca. Traktuje swoje przedsięwzięcie jako calkowicie subiektywne gdyż w pewnym sensie wybiórcze, pozostawiając miejsce dla następnych autorów, którzy być może będą chcieli kontynuować jej dzieło.

Praca Barbary Levine podzielona jest na cztery części. Pierwszą część stanowią ksiażki i artykuły o Johnie Deweyu, druga recenzje dotyczące dzieł Johna Deweya, trzecią indeks autorów i ostatnią indeks zawierający słowa-klucze.

Gdybyśmy chcieli przyjrzeć się uważnie każdej $\mathrm{z}$ wymienionych części $\mathrm{z}$ łatwościa można dojrzeć czytelność, z jaką zostały one opracowane, a stąd łatwość płynącą dla potencjalnego czytelnika.

Część pierwsza zawiera alfabetyczny spis autorów według nazwisk. Każdej pozycji został przypisany numer, aby ułatwić korzystanie $\mathrm{z}$ bibliografii układ ten pozwala na bardzo szybka orientację w zakresie zainteresowań danego autora i oczywiście ilości napisanych przez niego 
materiałów. Jeśli autor napisał więcej niż jedna pracę, to każda kolejna ułożona jest chronologicznie pod danym nazwiskiem.

W części drugiej autorka przytacza recenzje odnoszace się do wyszczególnionych alfabetycznie dzieł Deweya, co z kolei zwraca naszą uwagę na szerokie pole zainteresowań Johna Deweya i recepcje, która była odpowiedzią elit akademickich, jaka niosły jego dzieła.

Trzecia część zawiera alfabetyczny katalog autorów i wydawców oraz recenzentów.

Czwarta i zarazem ostatnia część stanowi bardzo interesujący spis, tym razem według słów-kluczy. Wykaz ten unaocznia nam w sposób oczywisty, w jakich dziedzinach recepcja Johna Deweya była największa. Mnogość autorów zajmujacych się takimi problemami, jak pragmatyzm, filozofia, demokracja, wartości, nauczyciel i nauczanie, logika i myślenie, religia, myśl i jej analiza, prawda i poszukiwanie prawdy, polityka, naturalizm, metafizyka, znaczenie i działanie, uczenie się, wiedza i sposoby jej zdobywania, istota dociekań filozoficznych i moralnych, humanizm, wolność, eksperymentalizm, doświadczenie, etyka, empiryzm, postęp, edukacja, curricuJum, świadomość, wspólnota, sztuka jako doświadczenie oraz sztuka i estetyka określa nam zarazem wszechstronność Johna Deweya i wielostronność ujmowania przez niego zagadnień bazujących na filozoficznych podwalinach pragmatyzmu $\mathrm{i}$ edukacyjnych progresywizmu.

Nie tylko jednak olbrzymi zakres tematyczny może wprawić w osłupienie ale także fakt, iż recepcja tegoż klasyka trwa nieustannie na przestrzeni tak wielu lat.

Książka Barbary Levine, dzięki swej rzetelności jednoznacznie ukazuje nam, że w poszczególnych okresach twórczości Johna Deweya od- biór jego dzieł budził wielkie zainteresowanie. Nawet jeśli prześledzimy lata czterdzieste, znajac zaangażowanie Stanów Zjednoczonych w druga wojnę światową spostrzeżemy, że artykuły stanowiące recepcję twórczości Johna Deweya nie traciły na popularności. Lata pięćdziesiate i sześćdziesiąte, kiedy zdecydowanie można mówić o odchodzeniu Ameryki od wychowania w szkołach aktywnych, szkołach z dominująca rolą zajęć praktycznych nie przestawano pisać o Johnie Deweyu. Lata osiemdziesiate i dziewięćdziesiąte zaznaczają się zdecydowanie, według chronologii autorki, jako ogromne ożywienie w obrębie recepcji myśli Johna Deweya.

Książka Barbary Levine stanowi znaczacy wkład w umoźliwienie gruntownego zapoznania się z twórczością Johna Deweya, właśnie przez dostarczenie bogactwa informacji dotyczącej odbioru jego dziel w jego ojczystym kraju.

Ogrom pracy, jaki wykonała Barbara Levine z pewnością ułatwi zainteresowanemu czytelnikowi dostęp do powyższego materiału. Logiczny sposób ułożenia treści eliminuje jakiekolwiek trudności, które mogłaby nastręczać lektura tejże książki w Stanach Zjednoczonych. Sądzę jednak, że na gruncie europejskim sprawa przedstawia się nieco inaczej, jeśli chcemy $z$ tej bibliografii skorzystać w sposób owocny. Nie jest to wystarczajaco łatwe, ponieważ autorka nie podała $w$ jakich bibliotekach w Stanach Zjednoczonych znajduja się dane materiały. W obecnych czasach ważną rolę spełnialyby adresy witryn intemetowych tychże bibliotek. Mankament ten powoduje, że odnalezienie przedstawionych materiałów może stwarzać pewne problemy. Nie ulega jednak watpliwości, że ta tytaniczna praca stanowi wielki krok w przybliżeniu J. Deweya i odbioru jego dzieł.

Hanna Brejnak

\section{Teresa Podgórska, Stowarzyszenie Patriotyczno-Religijne Eleusis w latach 1902 - 1914, Wydawnictwo Katolickiego Uniwersytetu Lubelskiego, Lublin 1999, ss. 157}

Nakładem Wydawnictwa Katolickiego Uniwersytetu Lubelskiego w 1999 roku ukazała się książka Teresy Podgórskiej, zatytułowana „Stowarzyszenie Patriotyczno-Religijne Eleusis w latach 1902-1914". Autorka w swojej pracy chciała przedstawić narodziny i działalność jednej z najbardziej kontrowersyjnych organizacji młodzieżowych, jaka istniała $w$ początkach XX 